\title{
INFÂNCIA E ADOLESCÊNCIA DE EXECUTIVOS NEGROS: UM ESTUDO RETROSPECTIVO
}

\author{
BLACK EXECUTIVES’ CHILDHOOD AND ADOLESCENC \\ A RETROSPECTIVE STUDY
}

SANTANA, I.; CAMARGO, C.L. Infância e Adolescência de Executivos Negros: Um Estudo Retrospectivo. Rev. Bras. Cresc. Desernv. Hum., São Paulo, 9(2), 1999.

\begin{abstract}
Resumo: Este artigo aborda situações vivenciadas na infância e adolescência por executivos negros de organizações bancárias com sede em Salvador (BA). Busca-se as intercorrências desse periodo de vida relacionadas à trajetória de ascensão social dos executivos estudados. $\mathrm{Na}$ apreensão da realidade desses sujeitos, utilizou-se o método de estudo de caso e a técnica de história de vida. O resultado da pesquisa revela que todos esses executivos vivenciarain infâncias e adolescência em familias de baixa renda, onde seus pais foram os principais incentivadores na busca da ascensão social, via qualificação educacional. A discriminação racial destacou-se como o mais vigoroso obstáculo na carreira, sendo enfrentada com estratégias individuais e específicas, norteadas pela "busca de ser o melhor, para ser aceito como igual". O estudo demonstra a forma desigual com que os negros se inserem no processo de ascensão social e a pequena quantidade destes indivíduos, que consegue atingir postos expoentes nas organizações. Uma trajetória marcada pela adoção de comportamentos que os distanciam do seu referencial étnico, onde vão eliminando propositadamente de suas vidas os valores culturais negros, elegendo o branco como modelo de identidade.
\end{abstract}

Palavras-chave: Racismo; Criança e trabalho; Família.

\section{INTRODUÇÃO}

“... quando eu terminei o curso primário em primeiro lugar, quem levou a bandeira brasileira foi o Julinho, porque a professora disse que ficava melhor, ele era branquinho, de cabelos lisos e olhos claros. Não liga, não, José Carlos. Você fica do lado...”

Nos últimos anos, no rol das publicações sobre o negro no Brasil, os temas relacionados à escravidão e abolição da escravatura tem atraído a atenção de vários investigadores cujos estudos demonstram a dimensão histórica, geográfica e social que os africanos e seus descendentes assumiram no continente. No entanto, é ainda compa- rativamente pequeno o número de pesquisas que exploram o universo do negro que ascende socialmente de modo a desvendar suas específicas trajetórias de crescimento e desenvolvimento.

Neste artigo são abordados aspectos da infância e adolescência de indivíduos negros, em que busca-se resgatar parte da trajetória de homens e mulheres que, segundo as pesquisas, dada a condição racial, pertencem às mais baixas posições na estrutura social brasileira. No entanto, no presente, estes indivíduos, trazem de especial a característica de formarem uma espécie de anomalia estatística: a de negros que conseguiram ser bem sucedidos em carreiras que no Brasil são exercidas quase exclusivamente por brancos. Es-

1 Mestrando em Administração de Empresas e Comércio Exterior pela Universidad de Extremadura. E-mail: ivosantana@hotmail.com.

2 Doutora em Saúde Pública pela Faculdade de Saude Pública - USP, Professora da Escola de Enfermagem da Universidade Federal da Bahia. End.: Morro Escravo Miguel, 184/201 - Salvador- BA - 40170-000. Fone: (0xx71) 332-0946. 
tas pessoas, ocupam postos de executivos em organizações apontadas em muitos estudos como de difícil inserção de negros em seu quadro funcional as organizações bancárias.

Ao evidenciar-se o passado desses indivíduos buscou-se compreender suas trajetórias, distintas da maioria da população negra, a partir da análise de suas falas reportadas à infância e adolescência - fases do desenvolvimento humano onde a personalidade é forjada e que consideramos importantes na aquisição dos valores que os influenciaram e determinantes na ascensão profissional.

São experiências vivenciadas na infância e adolescência por indivíduos que passaram pela experiência de lutar como negros em uma sociedade, de classe e ideologia predominantemente brancas. Sem sobrenomes pomposos, sem o respaldo da educação familiar, sem fortunas herdadas e sem qualquer vínculo anterior com a classe a qual atualmente pertencem. Estes são os executivos negros de organizações bancárias com sede em Salvador (BA), população do nosso estudo.

Vencedores, no que se propuseram, ainda que nesse caminho tenham se tornado ideologicamente "outros", respondendo positivamente ao apelo da ascensão social, o que segundo SOUZA (1983, p. 17) implica na decisiva conquista de valores, status e prerrogativas brancos “com todos os seus pressupostos e desdobramentos”.

\section{NOTAS METODOLÓGICAS}

Como estratégia de compreensão da realidade da infância e adolescência dos executivos negros, utilizou-se o método de estudo de caso e a técnica de "história-de-vida". O estudo de caso foi escolhido na metodologia norteadora por ser um meio de organizar os dados sociais preservando o caráter unitário do objeto social estudado e a composição das histórias de vida foi utilizada para possibilitar o estudo do processo de socialização dos executivos negros, a emergência de seu grupo étnico, as respostas situacionais e contingenciais cotidianas (DENZIM apud MINAYO, 1992 p. 17). HAGUERRE (1995, p. 83 ) também considera importante que as informações sejam levantadas sob o ponto de vista dos próprios atores para que assim se torne possível conhecer suas táticas, suas suposições, seu mundo, os constrangimentos e as pressões às quais estão sujeitos.

Poderíamos dizer, junto com esses autores que a história de vida verbalizada pelos participantes é instrumento privilegiado para se interpretar o processo social na medida em que se consideram as experiências individuais como dados que falam além e através delas. Para atender a essa condição a pesquisa foi desdobrada nas seguintes etapas:

a) Contato inicial com a área de Recursos Humanos dos bancos para identificar os executivos negros atuando em níveis de direção e gerência e para obtenção do perfil sumário da empresa.

b) Entrevista semi-estruturada com os executivos identificados.

c) Análise dos dados através da técnica de análise do conteúdo.

A pesquisa desenvolveu-se junto à organizações bancárias com sede na Bahia e, nas agências ou dependências localizadas na capital desse Estado em face da representatividade do número de estabelecimentos e das características étnicas da população de Salvador cuja maioria é composta de negros. Nessas condições computaramse quatro organizações.

Perfazendo um total de dez homens e duas mulheres, a população deste estudo é constituída por todos os profissionais negros, que no período de 10/03 a 05/04/97 ocupavam cargos de executivos em organizações bancárias sediadas na Bahia e em dependências localizadas na capital.

Escolhemos indivíduos apontados pelos setores de Recursos Humanos e que ao mesmo tempo, se auto-caractenzassem como negros. Tentamos, dessa forma, superar um problema, que BENTO (1992) admite ser comum na realização de pesquisa com negros ou seja, o fato de que por força da ideologia do branqueamento, nem todos os descendentes de africanos idenbficam-se como negros.

Por solicitação dos entrevistados a pesquisa envolveu um executivo não indicado pelos representantes de Recursos Humanos, provavelmente em razão do tom de pele pouco mais claro que os demais, legitimando a constatação de PIERSON (I 971. p.38) de que: “... tal como se emprega no Brasil ... cor significa mais que simples cal: isto é, mais que pigmentação [significa] inclusive. em primeiro lugar [a presença] de um certo nuúmero de outras características físicas: tipo de cabelo (talvez o mais importante) assim como os traços fisionomicos..."

Vale ressaltar que, os depoimentos se iniciavam, quase sempre, debaixo de certa defesa e de "cuidados" no falar, revelando, às vezes certa desconfiança com o destino das infonnações. Adotava-se o "jogo de retranca” claramente perceptível pelas respostas sempre em termos generalizantes. Passado alguin tempo, sendo "forçados” a lembrarem-se de coisas já julgadas esquecidas, se desenvolvia um clima de intimidade e cumplicidade. Muitas vezes havia a surpresa da percepção de caminhos individualmente percor- 
ridos e revelados naqueles momentos. Alguns dos entrevistados, num período de mais ou menos duas horas já se sentiam fatigados, dando mostra do esforço empreendido no trabalho de exposição de suas intimidades, conflitos, emoções. Outros no afã de "lembrar de tudo" ofereciam uma profusão de detalhes e circunstâncias.

Algumas vezes assistimos a pessoas se entristecerem, baixarem e levantarem a voz, indignarem-se, ou calarem-se de repente entre uma lembrança e outra. Vimos também sorrisos que inequivocamente ocupavam o lugar do desprezo, ou da perplexidade. Não captamos mágoas, nem revoltas.

Chegamos ao fim dos depoiinentos, refletindo sobre o caminho trilhado, lamentando o pouco tempo que, não nos penmitiu um maior aprofundamento, mas satisfeitos com os ensinamentos partilhados nas breves, porém profícuas conversas. O resultado das entrevistas está registrado em um acervo de 38 fitas gravadas. Ainda assim, no intuito de oferecer um retrato mais aproximado de cada entrevistado, traçaremos, a seguir, um perfil sumário de cada um dos doze execuúvos que deixaram registrada parte da sua história e das vivências em cargos executivos em organizações bancárias. Todos eles são, aqui, denominados por nomes fictícios:

Raimundo - Estatístico, 43 anos, casado, um filho adolescente, provém de uma família de seis irmãos. Seu primeiro emprego foi como Ajudante de Pedreiro, aos 18 anos, seguindo-se o de Sondador, na Petrobrás. Após trabalhar por um ano, abandonou o emprego para fazer um curso de informática na IBM e a partir daí exerceu funções de Programador de Computador em indústria siderúrgica e companhia telefônica estatal. Há 17 anos, ingressou no Banco exercendo as funções de Programador, Analista de Sistemas, Coordenador e Gerente. Nesse intervalo passou um ano no Extenor a serviço do Banco e atualmente ocupa cargo em nível de $3^{\circ}$ escalão na hierarquia do Banco C.

Sócrates - Engenheiro Civil, 45 anos, casado, pai de três filhos adolescentes. É o caçula de uma família de dez irmãos. Diferentemente dos demais executivos, toda sua fònmação escolar foi realizada em colégio de classe média alta. No primeiro ano financiada pelos immãos mais velhos e nos anos seguintes graças à bolsa de estudo, obtida em razão do bom desempenho escolar. Começou a trabalhar aos 17 anos como Topógrafo, depois, foi Analista de Sistemas em empresa estatal e sócio numa empresa de cálculos de estruturas. Após o fechamento da empresa, há 19 anos, ingressou no Banco C como Analista de Sistemas, passando por Coordenador e Gerente Geral até alcançar o atual posto de $3^{\circ}$ escalão. Há seis anos ocupa este cargo.

Cristina - Professora primária, 41 anos, solteira, é a primogênita de uma família de quatorze irmãos. Concluiu o curso de $2^{\circ}$ grau e começou a trabalhar num posto de gasolina. Aprovada em concurso público exerceu funções de Datilógrafa em empresa estatal até ser admitida no Banco B (também, via concurso público) como Auxiliar de Escritório, há 20 anos. Sempre exerceu suas funções em cidades do interior, mudando constantemente de funções e de cidades. Foi Caixa, Chefe de Escritório, e há 13 anos ocupa cargo de $3^{\circ}$ escalão no Banco B.

Maciel - Economista, casado, 53 anos, dois filhos. Tem apenas um irmão. Aos 20 anos começou a trabalhar como Auxiliar de Escritório numa indústria de confecções e, através de teste seletivo, há 33 anos, ingressou no Banco C como Escriturário. Anos depois, foi selecionado, através de concurso interno para integrar a equipe de reorganização da empresa de processamento de dados do Banco. A partir daí exerceu funções de Chefe de contas-corrente, Instrutor e Gerente até chegar ao cargo de $3^{\circ}$ escalão que ocupa há 9 anos.

Adriano - Graduado em História, ao seu currículo somam-se dois cursos de pós-graduação em Administração. Iniciou e não concluiu mestrado em História, além de cursos de graduação em Direito e em Economia. 35 anos, solteiro, um filho. Provém de uma família de dez irmãos e destacou-se em sua cidade de origem, como membro ativo de partido político. Aos 22 anos ingressou no Banco B através de concurso para a carreira de Escriturário e ocupa, há dois anos, cargo, em nível de $4^{\circ}$ escalão na hierarquia da empresa.

Angela - Pedagoga, com dois cursos de pós-graduação em Administração. Aos 34 anos é solteira, de origem rural, contando apenas uma irrnã. Começou a trabalhar aos 17 anos em uma escola infantil no interior como Secretária, depois Professora, até mudar-se para a capital onde realizou os estudos universitários e passou a lecionar em um colégio de classe média alta. Ingressou no Banco B, há 11 anos como Escriturária, exercendo paralelamente atividades educativas. Há um ano exerce cargo executivo de $3^{\circ}$ escalão.

André - Geógrafo, com cursos de pós-graduação em administração e em finanças. Abandonou curso de Jornalismo, 42 anos, casado, duas filhas, vem de uma família de seis irmãos. Em sua trajetória traz as experiências de ter sido Camelô, Atendente de escritório de advocacia, Auxiliar de serviços em imobiliária, Encarregado de escritório em loja e, Professor, em Universidade. Ingressou no Banco B, via concurso público, na função de Escriturário e há 05 anos atua no $2^{\circ}$ escalão da Empresa. 
Fábio - Estudante de Filosofia, 42 anos, casado, dois filhos, natural do interior da Bahia, é o primogênito de nove irmãos. Sua vida profissional passa por Aprendiz de Barbeiro, Funcionário Público, até chegar ao Banco B, há 23 anos, através de concurso público para Auxiliar de Escritório. Iniciou-se em agência do interior, de onde foi alçado a Chefe de Serviços, Gerente. Há 14 anos cargo de $4^{\circ}$, escalão na Empresa.

Paulo - Advogado, 36 anos, casado, dois filhos, é o segundo filho de seis irmãos. Seguiu a carreira do pai que se diplomou em Direito muitos anos depois dos filhos criados. Aos 18 anos, no primeiro semestre da Universidade, começou a trabalhar num escritório de advogacia de um professor paterno. Há 16 anos foi admitido no Banco B, como Estagiário, sendo depois contratado como Auxiliar Administrativo no Setor Jurídico, seguindo-se a Advogado e Chefe. Exerce cargo de $2^{\circ}$ escalão há 10 anos. Atua também como profissional liberal.

Edilson - Contador, Pós-graduado em Finanças, 36 anos, casado, um filho. Iniciou sua vida profissional aos 17 anos como contínuo em um outro banco. A experiência de contínuo tornou-o mais próximo de elementos chaves de diversas organizações, facilitando os relacionamentos e a troca de favores, de tal forma que aos 19 anos já ocupava o posto de Gerente Administrativo. Há 15 anos ingressou no Banco B, como Escriturário, através de aprovação em concurso público, Foi designado para a Chefia de Departamento antes de assumir há 7 anos, posto de $3^{\circ}$ escalão.

Eduardo - Jornalista e Advogado, 47 anos, divorciado, dois filhos. De origem rural, é o $2^{\circ}$ filho de uma família de dez irmãos. Filho de agricultores pobres foi o escolhido dentre os irmãos para completar os estudos primários, e concluir o curso de Magistério. Até os 21 anos, trabalhava na lavoura, sob o regime de meação, capinando, roçando e arando a terra. Aos 22 anos transferiuse para a capital onde ingressou no Banco B, como Escriturário, através de concurso público. Paralelamente ao Banco atuou como Jornalista. Tem 25 anos de Banco e 10 anos ocupando cargo de $3^{\circ}$ escalão.

Marcelo - Contador, 55 anos, pós-graduado em Auditoria, unigênito, casado, um filho. Iniciou sua vida profissional aos 18 anos como Auxiliar de Escritório em um laboratório, tornando-se em pouco tempo Encarregado de Faturamento. Trabalhou em diversas outras empresas atuando como Chefe de Escritório, Chefe de Cobrança, Tesoureiro. Há 28 anos foi convidado por um diretor para trabalhar no Banco A, chefiando um Departamento. Há 06 anos atua no $3^{\circ}$ escalão, exercendo paralelamente atividade de docência na
Universidade e de consultaria de empresas na área de contabilidade.

Estes foram os executivos focalizados neste estudo cujas histórias de vida relatadas nas entrevistas, nos levaram às reflexões que descreveremos a seguir.

\section{O DESENVOLVIMENTO NA FAMILIA DE ORIGEM}

"Um judeu branco entre brancos pode negar que seja judeu, declarar-se homem entre homens. O negro não pode negar que seja negro ou reclamar para si esta abstrata humanidade incolor; ele é preto.”

Jean Paul Sartre

A história da humanidade mostra-nos que, embora sob variadas formas, e ainda em evolução, as famílias sempre existiram e têm papel fundamental na formação da personalidade dos indivíduos (BRUSCHINI, 1981, p. 35). E, sobretudo, durante a infância e a adolescência que sua influência se faz acentuada, especialmente na reprodução ideológica resultante da transmissão cotidiana de valores. Através da família, a criança se integra ao mundo adulto. Aprende a canalizar seus afetos, a avaliar e selecionar suas relações (PRADO, 1981). Diante disso, a família passa a ser o lugar primeiro em que a criança aprende e assume posicionamentos dentro de um conjunto de papéis socialmente definidos, e mais que isso, é através dela que recebe orientação e estímulo para ocupar um determinado lugar na sociedade adulta.

Os entrevistados, são, todos, originários de famílias da classe trabalhadora, algumas com grande número de filhos e cada qual com sua história de sobrevivência marcada por necessidades econômicas, sofrimento e luta pela vida, no dia-adia, como revelam as seguintes falas;

“... a gente nunca passou fome, assim aquela coisa toda não. Mas dificuldades financeiras passamos... Éramos 10 irmãos.” (Adriano)

"Eu me lembro que uma vez meu pai comprou uma meia preta, e era de qualidade tão ordinária que ia mudando de cor, ficava azulada. Eu não tinha dinheiro para comprar outra, ela tinha que durar o ano todo. A diretora fazia uma inspeção de vez em quando e quem não estivesse com a meia preta, ela mandava ir pra casa... ela me botou na frente, olhou minha meia e ficou na dúvida se era preta. Eu tinha certeza que era preta. Chamou o professor que estava dando aula, para ele dar a palavra definitiva e ele disse: $\mathrm{Pa}$ rece mais cor de mula ruça... Pelo sim, pelo não, vá pra casa..." (Eduardo) 
"eu sou filho único e meus pais eram muito pobres... como todo filho de pobre, precisava trabalhar e eu tive que procurar algum lugar para trabalhar e também estudar à noite... me transferi para a noite." (Edilson)

Têm em comum um lar e uma família nuclear que consegue suprí-los nas condições mínimas de sobrevivência. Uma família que é responsável pelas garantias materiais, morais e afetivas de seus filhos e que aparece nos depoimentos como cumpridora de suas obrigações através da influência, orientação e incentivo dos pais.

“... minha vida no inicio, foi extremamente difícil, mas o sacrifício do meu pai foi muito grande. Eu diria que ele saiu raspando, tirando as principais arestas e permitindo que a gente realmente tivesse uma vida mais fácil, embora com muita limitação...” (Raimundo)

“... meu pai me ensinou uma coisa que me ajudou muito... tipo assim lá no interior a regra do menino pobre e preto é carregar balaio dos ricos e brancos, e meu pai decidiu terminantemente que os filhos dele não fariam isso; isso nos tornou desaforados para os outros e aí tinha discussões terríveis, e eu trouxe esse desaforo prá a vida, às vezes dissimulado..." (Eduardo)

“... meu pai fazia tudo por mim, então dizia o seguinte: você não precisa trabalhar agora para poder ganhar bobagem. Você vai ter que lutar para poder ganhar melhor, para poder subir na vida. Isso, realmente, em termos de formação na família, foi muito bom. Esse negócio de honestidade, de falar para a pessoa assim de frente, de poder encarar as pessoas sem medo, isso eu trago de família, isso não tem dúvida..." (Adriano)

\section{A RESPONSABILIDADE PRECOCE}

Observa-se em algumas falas dos entrevistados, a consciência da responsabilidade que precocemente lhes é delegada no ambiente familiar. Esta responsabilidade, vem sempre acompanhada da manifestação do desejo de corresponder às expectativas dos pais:

“... meu pai viajava muito... já deixava o dinheiro do mes em minhas mãos, e eu desde os 10 anos era quem administrava as despesas $d a$ família... Eu praticamente amadureci antes da época. Então eu tinha muita confiança do meu pai, da minha mãe, e eu administrava muito bem a economia doméstica dai eu acho que as duas coisas se uniram bem: meus pais sentiam muito orgulho de mim e eu procurava corresponder dentro das expectativas deles...” (Adriano)
“... minha mãe sempre cobrou de mim isso... meu pai ganhava dinheiro fácil. Trabalhava no cais do porto. Saia no carnaval e voltava 3 dias depois... ele tinha problema de bebida. Então minha mãe se agarrou a mim... e cobrava de mim... e eu sempre correspondi à altura..." (Maciel)

Nesta perspectiva o núcleo familiar se apresenta como o lugar primeiro onde o executivo negro desenvolve a interiorização de exigências e ideais a serem cumpridos. “...É ai onde se cuida de arar o caminho a ser percorrido antes mesmo que o negro, ainda não sujeito, a não ser ao desejo do Outro, construa o seu projeto de chegar lá. Depois é a vida de rua, a escola, o trabalho, os espaços de lazer...” (SOUZA, 1983, p. 36)

\section{A EXPERIÊNCIA DA DISCRIMINAÇÃO}

As "vigas mestras" consolidadas na adolescência foram erigidas no ambiente familiar. São instrumentos de proteção e incentivo na vida desses indivíduos. Contudo "a vida de rua”, fora do convívio dos pais faz com que sejam incorporadas novas experiências, novos significados, exigências e papéis a serem desempenhados. Nesse contexto, o apoio familiar não foi o bastante para que esses sujeitos deixassem de sentir os efeitos da violência fruto da representacão do negro como ser socialmente inferior que, certamente, os vitimizou na infância. Conforme mostram as falas seguintes, esses indivíduos, tornaram-se alvos fáceis de atitudes discriminatórias, em razão da dupla condição a que estavam sujeitos: Ser negro e ser pobre.

“... essa questão racial sempre existiu... e isso e uma coisa com que eu nunca me preocupei, esse problema de racismo, por isso que eu nunca senti nada, nunca procurei me aprofundar. porque eu também tive esse convívio, minha mãe branca, meu pai negro. Nunca me preocupei... Agora penso muito em mim. Minha avó por exemplo, o neto preto que ela tinha era eu, e aí minha avó nunca me chamava pelo nome quando ela queria reclamar: o seu preto!!! nunca dizia, meu filhinho, meu netinho... Minha mãe, às vezes ficava meio... (silêncio)... mas as coisas passam... eu acho que a gente se acostuma...” (Marcelo)

“... eu sofria. Sofria o preconceito racial que era muito (silêncio)... nego não me chamava pelo nome. Me chamavam de preto, de escurinho, ou de qualquer coisa parecida, mas não me chamava pelo nome.

P - Chamavam de Pelé?

$\mathrm{R}$ - Pelé não. Penso que eles achavam que Pelé era um elogio. Chamavam de coisa pior. E o 
preconceito... era uma coisa terrivel que destruia qualquer mente infantil ou de adolescente... (Eduardo)

$$
\text { “... eu fui muito discriminada pelo falo }
$$
de ser a mais humilde do meu grupo. Na formação de equipes as pessoas mais socialmente relacionadas ficavam juntas. Me integravam porque eu era inteligente, e sabia mais. Mas eu nunca era a chefe da equipe. Nunca fui secretária. Diziam que a minha letra era horrível... Eu sempre era uma componente que colaborava muito... Eu sempre ficava muito triste com isso... Reperguntava: Meu Deus!! porque sempre componente?... a turma gostava de estudar na casa de J. que era rica, e quando perguntavam: J. 1, não vai sair uma merendinha, não? Ela imediatamente me chamava: Vá ali na padaria comprar um pão. Até que um dia eu disse: Puxa! J., só porque eu sou preta eu tenho que ir atravessar a rua para comprar o pão... mas eu fui assim mesmo...” (Cristina)

Os efeitos dos atos discriminatórios parecem ter se refletido na auto-imagem e no comportamento desses indivíduos. Os executivos do sexo masculino aludem terem vivenciado adolescências tímidas perrneadas de dificuldades nos relacionamentos com as pessoas.

“... nos dias de chuva eu tinha um saquinho plástico prá botar meus livros e cadernos e levar prá escola... hoje eu vejo como interessante, mas na época eu não tinha essa percepção... tanto que a conseqüência, era que eu me fechava muito... e tive dificuldades de relacionamento... na escola eu tive muita dificuldade de relacionamento..." (André)

“... eu era extremamente tímido, tinha vergonha, até de dizer presente' na hora da chamada... percebia que pela timidez, ficava sempre vencido. Superado naqueles meus desejos, que deixava sempre para trás apenas pelo medo de aparecer. Ai foi ficaído mais claro, que isso era extremamente danoso...” (André)

"... eu acho que poderia estar mais adiante na minha vida profissional. Talvez pudesse estar mais desenvolvido. Você 'fica naquela' de pedir licença o tempo todo e aí começam os problemas. Você não entra, você não fura as coisas e aí fica difícil, faz um esforço maior pra conseguir as coisas porque não tem a liberdade de dizer: eu quero que fulano me arranje. Você tem que fazer com que as pessoas entendam..." (Adriano)

Diferentemente dos homens, as executivas entrevistadas demonstraram ter desenvolvido, na infância, comportamentos agregativos e de extroversão. Seus relatos denotam formas de relacionamento que se caracterizam por trocas e negociação de dependências recíprocas assumindo a subordinação como forma de serem aceitas pelo grupo. Sugerem aproximação com pessoas que lhes podem contrabalançar os “defeitos” (ser pobre e ser negra). Ao retratarem suas companhiasl as referências utilizadas são: rica, branca, bonita, cabelo liso, ou a partir da propriedade de bens materiais.

“... nunca fui timida. Sempre participei de tudo... e tive um excelente relacionamento com todo mundo... Tinha o $B$. que era meu colega... e as condições dele eram superiores às minhas, morava na fazenda ao lado... Eu só andava na bicicleta dele, tudo meu só era com o B. Eu tinha uma outra amiga era a J. que tinha uma casa que era uma senhora casa. Lá tinha um gabinete... e ela era sempre a líder (nos trabalhos de grupo)... A casa dela era tão poderosa que eu não esqueço nunca. B era poderosa... Ela era rica e tinha o cabelo liso, ... era como se existisse uma dependência de minha parte para com ela, entendeu?" (Cristina)

"... sempre participei de tudo, agora sempre fiz o papel de escrava ou de carrasco. Participava de tudo e nunca me importei... se ia ter a peça de Tiradentes quem seria o carrasco? Quem iria enforcar Tiradentes? Eu. Porque era a negra da sala...” (Cristina)

“... eu sempre procurei fazer boas amizades com pessoas que podiam me dar algo e sempre de forma apolítica, ao lado de todos. Eu sempre fui uma pessoa carismática e sempre me sai bem em todos os ambientes quefrequentei..." (Angela)

\section{SUPERAÇÃO DE OBSTÁCULOS NA INFÂNCIA E ADOLESCÊNCIA}

A timidez e a dependência vivenciadas na infância foram identificadas pelos entrevistados como os maiores obstáculos a serem enfrentados. Ainda assim foi a dificuldade de se expressarem que representou a batalha primeira a ser vencida a todo custo. A posição de fragilidade em que esta dificuldade os colocava, impedia-os da manifestação de suas potencialidades, imobilizando-os. Nesse sentido CLASTRES (1986, p. 106) mostra que “... falar é antes de tudo deter o poder de falar: Ou ainda o exercício do poder assegura o domínio da palavra e só os senhores podem falar. Quanto aos súditos, estão submetidos ao silêncio do respeito, da veneração ou do terror. Palavra e poder mantêm relacionamentos tais que o desejo de um se realiza na conquista do outro (.. J. Toda tomada de poder é também uma aquisição da palavra..." 
Como se pode ver, os sujeitos estudados descobriram que necessariamente teriam que se sobressair de alguma forma:

"... ou você se destaca de alguma maneira ou você fica pra trás e em tese não me destacava em nada. Com o passar do tempo, eu consegui superar... forcei a barra mesmo.... eu percebi o seguinte: Eu preciso marcar minha presença e falar. Eu não tenho que esperar que as pessoas percebam. Eu vou ter que dizer: Cheguei...” (Adriano)

“... desde o curso primário eu já me aborrecia porque via que as portas do mundo se abriam para os outros e eu não podia entrar porque a timidez não me permitia. Eu tinha certeza que se eu continuasse assim não seria ninguém, seria extremamente apagado. Como eu fiz? Travei uma luta interna, uma briga interna para superar aquilo...” (André)

Ou mudar de comportamento:

“... teve um dia que eu disse: vou me libertar (da dependência de J.) porque teve uma vez que J. f cou atrás de mim e pediu uma 'pesca' $e$ eu disse: Um momentinho, deixe eu terminar de fazer (a prova) e não dei (a pesca). Ai ela foi pra casa e a mãe dela me chamou (para reclamar). Nessa hora eu disse pró mim: Quer saber de uma coisa? eu vou me libertar desse povo todo, e pronto... não quero mais saber dos trabalhos daquela equipe..." (Cristina)

Através dos relatos, observa-se que muito cedo incutiram-lhes a idéia que a educação era a forma mais garantida de "subir na vida" e adquirir o verniz necessário ao distanciamento dos estereótipos tradicionais que definem o negro como inferior política, social e culturalmente. No entanto, ao ingressarem na escola enfrentam uma realidade plena de obstáculos muitas vezes extremamente sutis já que, “.... as idéias pedagógicas se manifestam na tentativa de a concepção de mundo da classe dominante se tornar totalizante...” (CURY, 1985, p. 94).

O ambiente da escola brasileira se caracteriza por uma produção didática voltada para os valores culturais brancos de toda ela - "implícita ou explicitamente, afirma ou insinua a superioridade do branco, da sua cultura, dos seus padrões normativos e sociais em relação aos padrões africanos e dos negros de um modo geral" (MOURA, 1995). Nas escolas, as culturas grega, romana e ocidental são, via de regra exaltadas dentro de um currículo que prima pela eliminação ou pela íntima presença de tudo aquilo que seria um referencial esclarecedor sobre a África, seus heróis e a contribuição desse continente ao processo civilizatório. Os descendentes de africanos teriam herdado assim, os elementos da barbárie de seus an- cestrais, impermeáveis à civilização, aos valores e padrões culturais mais elevados. Diante destas concepções podemos entender o quanto a introjeção dos valores do branco terminou por intensificar em cada um destes indivíduos o propósito de "ser o melhor" - para ser aceito, pelo menos como "igual". Igualdade perseguida sob a perspectiva de um referencial que não lhe é próprio, mas que pretensamente o conduziria à libertar-se de uma ligação ancestral internalizada como inferiorizante.

Nas falas dos entrevistados percebe-se que o empenho escolar sobressaía-se dentre as estratégias utilizadas para superação das dificuldades na infância e adolescência. E foi no melhor rendimento escolar, reforçado pelo bom comportamento que se centraram os esforços desses sujeitos. Empenharam-se com afinco no intuito de "ser o melhor". E conseguiram:

“... sempre tirava notas boas, consideradas as melhores das turmas que eu freqüentava. Eu era chamado de CDF... Foi assim em toda minha trajetória...” (Sócrates)

“... sempre tive média no intervalo de 9 a 10. Eu era sempre um dos melhores alunos, tanto em comportamento como nas notas..." (André)

"... tinha comigo o seguinte: pra ser alguma coisa você tinha que ser o $n^{\circ} 1$... tinha que estar na frente... muitas pessoas estudavam comigo porque o destaque que eu tinha era mais em termos de nota, de estudo, principalmente na área 1 (matemática, química, física). Eu antecipava os assuntos da aula, pesquisava outras fontes e criava dúvidas interessantes na sala...” (Raimundo)

“... eu sempre fui uma excelente aluna... pelo fato de eu ser negra, procurava me destacar mais...” (Cristina)

\section{O SENTIMENTO IMPULSIONADOR NA CARREIRA}

Os executivos estudados, precocemente, introjetaram a idéia de que tinham que ser os melhores e se esmeraram para isto na adolescência, pela via escolar. Ainda que, na vida adulta esse sentimento permaneça, reelaborado sob nova roupagem na trajetória profissional e, reproduzindo o discurso: "se o branco mata um leão, o negro tem que matar dois" ou "o negro tem que trabalhar dobrado". Este discurso e as ações dele resultantes, torna estes indivíduos distintos dos demais, iniciando-os na escalada profissional.

“... você tem que mostrar muito mais. Você tem que mostrar mais valor, tem que ser melhor do que razoavelmente seria exigido para você che- 
gar a determinados pontos e isso é inegável... infelizmente. Efetivamente o negro para alcançar determinadas funções tem que ser melhor do que seria razoavelmente exigido para qualquer outra pessoa, na mesma situação. Foi assim em tudo que passei na minha vida. Foi assim que eu consegui efetivamente destaque com os trabalhos da escola, foi assim que consegui ser disputado na formação de grupos para a execução de trabalhos na escola e no Banco, porque numa situação normal eu não teria efetivamente esse espaço. Ah! Isso eu tenho muito claro...” (André)

“...primeiro, tem que ser melhor em tudo, ter determinação, coragem, perseverança. Por ele ser negro, ele é discriminado, então ele tem que ser melhor em tudo, na comunidade, no trabalho, fora dele. melhor que os outros, porque a cor pesa sim...” (Angela)

Nas falas que repetem as concepções que os sujeitos desenvolvem a respeito de si mesmo na trajetória de vida observamos que são enfáticos em apontarem comportamentos considerados importantes no processo de mobilidade social.

\section{ATRIBUTOS APRIMORADOS AO LONGO DA TRAJETORIA}

a) dedicação:

“... na medida em que você se dedica, você consegue. A questão não é ser mais ou menos inteligente, mas sim o fato de dedicar-se mais..." (Paulo)

b) competência e determinação

"... tive capacidade. Tive coragem e determinação para estar lá...” (Angela)

“... minha vida foi procurar estudar, ser competente, por necessidade realmente de crescimento, sem dúvida... agora por ser negro mais ainda, tinha aquela vontade de fazer as coisas para mostrar que tinha competência, que realmente queria chegar lá...” (André)

"... Por eu ser mulher e de cor... não deixei que isso me abalasse, porque eu não vejo cor nas pessoas, eu sempre procurei mostrar capacidade, determinação. isso que fez a minha diferença, entre as pessoas..." (Cristina)

"... eu não me canso quando estou animado com uma coisa. Eu durmo pouco e até nem durmo para terminar uma coisa que eu esteja fazendo... eu sou determinado." (Paulo)

c) perfeccionismo

"...f fazer a coisa assim... da melhor forma que eu sabia fazer... Eu não fazia um pouco menos, pra ficar mais fácil simplesmente por isso...
Eu poderia fazer um pouco menos quando isto fosse o melhor a ser feito... nunca para facilitar..." (Sócrates)

“... eu sempre quis ser o primeiro. Eu nunca quis ser o segundo ou o terceiro em nada eu nunca quis ser visto como bom" nem o bonzinho. Eu sempre entendi que tenho que ser o melhor. Eu sou muito perfeccionista..." (André)

d) ponderação

“... até hoje, quando estou tratando de um assunto novo eu ouço muito... é para eu poder aprender, entender do que está se falando. Quando eu dava minha opinião eu dava sabendo o que estava falando...” (Sócrates)

"... quando eu estava ouvindo, eu estou ouvindo para entender... eu não ouvia para dar respostas e é uma situação que eu não gosto quando estou conversando com alguém e a pessoa está do meu lado ouvindo, e antes que eu conclua já esta respondendo, como se já estivesse com a resposta pronta. Ela não está respondendo nada, ela está dizendo o que está querendo dizer e ponto final." (André)

“... ouvir as pessoas para mim é uma coisa importante. E depois me colocar quando tiver uma colocação clara. Quando não tinha, eu não inventava, dizia: não sei...” (Paulo)

e) obstinação

“... eu acho que (minha característica principal) sempre foi a obstinação. Inegavelmente é a obstinação. Outro dia estava pensando sobre isso, quando eu desejo muito profundamente uma coisa eu começo a trabalhar para que as coisas aconteçam e vou fundo...” (Sócrates)

“... se alguém me entregasse algum tipo de problema que eu não conseguisse resolver na hora, eu ficava possesso. Era inconcebivel pra mim que alguém me entregasse um problema de matemática ou de física, duas matérias em que eu me saia melhor e eu não tivesse uma solução.... Eu tinha que ter... era uma cobrança, talvez..." (Raimundo)

“... eu tenho esse pensamento desde os 14 anos de idade. Quando eu comecei a trabalhar eu pensava: sou pobre, sou preto, não é que eu tenha complexo, mas tenho que estar na frente porque se eu empatar com um branco, é ele quem vai ganhar... então eu sempre fui obstinado, obcecado nas coisas que eu quis...” (André)

A dedicação, competência e determinação somadas à ponderação são atributos já nutridos pelos sujeitos desse estudo antes de iniciarem a vida profissional e que acabaram aperfeiçoando com o decorrer do tempo. A seriedade e a noção de responsablidade, são, também, atributos repor- 
tados à fase juvenil. Certamente a existência dessas características contribuiu para a alavancagem aos cargos que passaram a ocupar.

\section{A CONDIÇÃO RACIAL COMO OBSTÁCỦLO}

É fato comum em muitos dos depoimentos que, ao início dos relatos, dada a pouca intimidade entre o entrevistado e os entrevistadores, muitos negam terem vivenciado experiências discriminatórias. Estas situações tornam-se compreensíveis à luz de FEAGIN \& FEAGIN (apud BENTO, 1992) "porque a maioria dos sujeitos tende a fazer ou a dizer o que seu grupo de referência espera que façam ou falem". (Maciel)

“... nunca senti nenhuma discriminacão...”

“... essa questão, realmente, aí vem o problema do racismo, eu não sofri em momento algum, porque eu sabia me impor...” (Raimundo)

“... eu estou dizendo que não senti essa questão do racismo porque a situação normalmente era o inverso. As pessoas dependiam de mim. eu dependia pouco delas. Então isto mascarou muito a questão do racismo...” (Sócrates)

Alguns entrevistados em seus discursos iniciais buscam consumir uma imagem de indiferença ou do alheamento quanto à discriminação sofrida, muito embora isso seja, sempre, dito com certo embaraço.

“... eu não posso dizer a você que eu nunca fui discriminado, mas eu nunca dei importância a isso, e por isso sempre trabalhei de maneira despreocupada. então, se eu quis fui atrás, eu estudei, trabalhei e o resultado veio. O reconhecimento foi em conseqüeneia disso.” (Paulo)

“... eu tinha consciência do problema, é um problema até hoje. Eu tinha a certeza de que as dificuidadas seriam maiores, tá certo? Mas por outro lado eu não dei muita relevância a isso. Eu sabia, mas ao não dar muita relevância e me preocupar com o que é principal, eu terminei vencendo este processo mais fácil.” (Edilson)

“... eu nunca procurei me aprofundar. Pode ser até erro meu. Eu penso mesmo é em mim. Eu tenho que cuidar primeiro de mim...” (Raimundo)

Vale ressaltar que em todos os casos estudados, a vivência da discriminação é admitida no seguimento dos relatos. Às vezes sob a forma de confissão. Outras vezes sob a forma de humor, como se fossem fatos pitorescos e engraçados. $\mathrm{O}$ que talvez fossem mesmo, cômicos, se não fossem trágicos.

“... estava iniciando no Banco (como office boy) e ele me disse: tem um detalhe: não gosto de preto. E completou usando uma expressão chula - porque preto quando não caga na entrada, caga na saída. Me disse tanto desaforo que eu não conseguia dizer nada e eu me derramei em lágrimas... Pois é, anos depois eu fui ser o chefe dessa pessoa..." (Marcelo)

A discriminação racial (direta ou indireta) é apontada como um dos principais obstáculos vivenciados na trajetória profissional e reconhecida por todos como um grande desafio para que se lançassem com afinco em seus propósitos de ascensão.Contudo, a discriminação sofrida é dimensionada, como um obstáculo, nunca como fator inibidor.

“... já houve casos da pessoa dizer assim: Puxa,, aquele negão, lá, tá fazendo o que? - Alié o lugar dele ? - Isso sem nem ter conversado comigo.... Às vezes eu estou numa mesa grande com mais duas outras pessoas, quando eventualmente chega alguém, solicitando informações, se dirigem aos outros...” (Fábio)

“... com o tempo a gente vai aprendendo a identificar a discriminação que no passado a gente não via e se tornando expert em observar e identificar... e reagir também..." (Cristina)

Os obstáculos encontrados foram superados a partir de estratégias traçadas individualmente no intuito de salientarem-se de maneira positiva no ambiente em que estavam inseridos. Nesse sentido devotaram-se aos seus propósitos de ascenderem socialmente, via:

a) extrapolação do nível de dedicação às atividades;

Esforçaram se mais para a obtenção de resultados notáveis, dedicando-se mais que os outros às suas atividades e esmerando-se nas posturas;

“... procurava ser bem polido, o máximo educado, eu procurava não ser agressivo realmente com as pessoas. Às vezes eu tinha agressividade guardada, mas eu não manifestada...” (Marcelo)

“... eu acho assim, que eu era uma pessoa que era mais fácil de concordar, então eu não criava dificuldades, não criava dificuldades...” (Fábio)

“... essa questão de estar se comparando com alguém, querer crescer... eu sempre coloquei isso na minha vida. Até no trabalho. Quando me entregavam uma tarefa, a mesma tarefa que entregavam a outra pessoa, eu procurava fazer o máximo para chegar a fazer melhor. Isso eu semprefi z... " (Cristina)

“... eu acabava fazendo de tudo, desde receber até entregar... botar debaixo do braço... descer escadas e entregar mesmo..." (Paulo)

A busca de ser o melhor- dado unânime em todas as histórias de vida- é, segundo SOUZA 
(1983, p. 40), a estratégia usada para se afirmar, para minimizar ou compensar o "defeito", e ser aceito. Ser o melhor é um lema introjetado, assimilado e reproduzido.

\section{A INTROJEÇÃO NEGATIVA DO MODELO NEGRO}

O processo de desenvolvimento pessoal desses indivíduos traz à tona estados de consciência étnica e social (ser negro e ser pobre) que envolvem duras batalhas consigo mesmo, que resultam numa tensão que parece ser constante e que permeia toda a vida social.

Assim, quando vão se defrontando com as dificuldades, a percepção de que são negros e pobres fica mais acentuada, porém as estratégias de superação das dificuldades são pensadas em torno de sua realidade étnica.

“... preto pra mim, quando eu era garoto, era aquele preto mesmo, azulado, não me achava preto, depois que eu fui descobrindo. Pô! qual é rapaz! sou preto mesmo, quando eu era garoto eu não tinha essa noção que eu era preto, não me sentia tão discriminado... depois é que eu comecei a ver e a me segurar mais...” (Eduardo)

“.' ',3.. eu, quando sentia que pela minha cor ia ser discriminada, eu procurava me arrumarpara ter uma boa aparência. Mefalavam muito sobre a necessidade de procurar se apresentar bem, ter boa aparência. O que é boa aparência? Eu sempre entendi como maneira de vestir, não é porque é preto ou branco, não, mas lá fora. boa aparência é branco mesmo...” (Angela)

A descoberta de ser negro nada mais é que a constatação do óbvio. No entanto a forma como este ser é internalizado leva-os a tornarem-se mais seletos nos relacionamentos e a redobrarem os cuidados na aparência pessoal. Procuram diferenciar-se da representação de negro internalizada e com isso aumentar as possibilidades de êxito e de aceitação.

"... quando eu ia tratar com uma pessoa, eu sempre procurava chegar cheio de cuidados, porque se eu chegasse falando alto como eu via muito branco fazendo, iam dizer logo: olha o crioulo ali... Então eu respeitava, eu tomava meus cuidados...” (Maciel)

"... nunca aconteceu essas coisas de racismo comigo não. Acho que é porque eu sempre me impus. Eu sempre fui muito fechado e de pouca conversa.... talvez andar arrumado tenha me ajudado...” (Marcelo)

Nesse sentido, o seu grupo de origem aparece como referência negativa. Como um lugar de onde há que se escapar para realizar indivi- dualmente as expectativas de mobilidade vertical ascendnte. Essa dinâmica é caracterizada por SOUZA (1983, p. 22) como a associação da ideologia do embranquecimento com os pressupostos do mito da democracia racial - a inexistência de barreiras de cor e de segregação racial - resultando no crescente desestímulo à solidariedade do negro, que se vê submetido a encarnar o "figurino do branco". Neste enfoque se ele ascendeu, todas as pessoas iguais a ele podem ascender, desde que saibam se comportar.

Como se isso não bastasse, precisa conformar-se aos papéis sociais ambíguos do "cavalheiro por exceção". Em todas as circunstâncias cativo a dar provas ultra-convincentes de sua capacidade de ser, de pensar e de agir como equivalente moral do branco. E então, para poder afirmar-se socialmente, condena-se a negar-se duplarnente, como indivíduo e como parte de um grupo racial

“... então eu sempre me portei de uma maneira correia, nunca gostei de balbúrdia, me vestia também dignamente né, sempre procureifazer boas amizades. ..” (Angela)

"... traçei uma meta... desde a melhoria do vocabulário, falar bem e não usar girias..." (Edilson)

“... o negro tem que se impor, andar de cabeça erguida, dizer sou negro e fulano de tal é branco e dai? isso não significa nada..." (Raimundo)

“... Eu pensava. Puxa, já sou negra e se me vestir mal... aí neguinho vai cair matando; então para ser bem recebida, eu procurava sempre estar bem vestida...” (Cristina)

Como diz SOUZA (1983, p. 27), "o negro toma o branco como referencial para afirmar-se ou para negar-se". Não Ihe cabe simplesmente ser - há que estar alerta; não necesssariamente para agir mas sobretudo para evitar situações em que seja obrigado a fazê-lo abertamente.

É neste contexto que o negro tem que "se impor” (através da postura e/ou da competência), o que significa: colocar-se de modo a evitar ser atacado, violentado e discriminado. Como consequência: perde a espontaneidade.

A vida para a criança e o adolescente negro costuma ser mais dura que para os brancos. Eles são obrigados a conviver, embora muitos neguem este fato, com comentários jocosos muitas vezes de mau gosto e enfrentar situações difíceis de lidar.

“... eu ouço muitas piadinhas em relação a outras pessoas. Em relação a mim, não. Mas é aquela história. A coisa está no nível de respeito àquele prá quem a piada foi feita. Muitas vezes é porque o sujeito dá espaço. Eu tinha um colega 
na escola, o D. que era negro e era racista. Só que, racista pelo lado dos negros. Ele brigava, ele discutia, ele batia boca... eu sempre ficava na minha... não era comigo...” (Sócrates)

\section{O DISTANCIAMENTO DO UNIVERSO CULTURAL NEGRO}

Nesses indivíduos observou-se a ausência quase que total de participação em algum tipo de atividade ou manifestação cultural, religiosa ou não, relacionada com a sua condição étnica. Nas suas relações de amizade o contingente de negros é diminuto em relação ao de pessoas brancas.

"... ainda hoje, tenho poucos amigos negros, pouquíssimos, até diria assim, quase nenhum. Questão de trajetória mesmo, eu fui buscar uma trajetória, um caminho que me distanciou.. Os lugares por onde eu passei e comecei a ocupar, eles se constituíram em lugares onde ser negro era exceção... eu também nunca fui ligado com esse negócio de movimento negro... até hoje, eu não sou chegado a esse tipo de discussão. Eu não gosto..." (Paulo)

“... Eu gosto mesmo é dessa parte folclórica dos negros, mas nada do tipo uma participação efetiva. Eu nunca freqüentei nem participo dessas questões raciais... Eu adoro ver a musicalidade deles desde o Milton Nascimento até o Olodum. Eu sempre levo meus filhos prá ver...” (Sócrates)

“... eu não gosto de me meter nessa coisa de questão racial, porque eu sou uma pessoa que vive completamente prá mim. No meu modo de entender: pessoas são pessoas em qualquer circunstância... Nos Estados Unidos os negros falavam comigo só porque eu era negro... Eu achava isso impressionante. Lá eles criam uma barreira. Vivem separados prá se protegerem. Aqui a gente também tem que lutar e existem grupos aí, que lutam por essa liberdade, mas eu não tenho aproximação porque eu realmente nunca tive esse problema de cor..." (Raimundo)

“... não tenho relacionamento ou freqüencia a eventos de movimento negro. $\mathrm{Na}$ verdade, sempre fugi dessas atividades que não me dão recursos. Não gosto muito de trabalhar de graça...” (Marcelo)

\section{CONSIDERA,COES FINAIS}

Ao remontar-se ao passado dos executivos negros pudemos evidenciar a situação de violência, às vezes cruel, que esses indivíduos experimentaram numa sociedade onde práticas discrrminatórias figuram como elementos importantes na reprodução das desigualdades entre negros e brancos.

Deste estudo sobressai uma realidade incontestável: por força do preconceito e das dificuldades atribuídas à cor da pele; o cotidiano destes jovens é farto de batalhas silenciosas, veladas e, em alguns casos, de confronto aberto, no combate a atitudes discriminatórias. E, é no intuito de minimizar os efeitos das atitudes discriminatórias sobre suas consciências que eles passam a desenvolver posturas moldadas no branco como modelo de identificação "como uma oportunidade de tornar-se gente” e a adorarem estratégias de contraposição a estereótipos inferiorizantes a que indivíduos negros são normalmente submetidos.

$\mathrm{Na}$ análise de seus discursos percebe-se uma variedade de estratégias utilizadas na superação de dificuldades. Muitas dessas estratégias os remeteram à introjeção de valores e pressupostos autodepreciativos. Outras estratégias os levou à incorporação de atitudes que, certamente, contribuíram para distanciá-los do envolvimento e relacionamento com indivíduos, instituições, eventos e até mesmo discussões referenciadas ao grupo racial do qual fazem parte.

A infância pobre encaminha-os para uma prática política de sobrevivência que explicita-se em "se dar bem com todo mundo" e na adolescência esta política serve de negociação do status nas relações individuais que lhes permitem atingir o objetivo a que se lançam. Todos vieram de famílias pobres, cujos pais asseguraram-lhes a educação e a sobrevivência à custa de grandes sacrifícios.

Na função de orientadores seus pais foram também os maiores incentivadores na busca de qualificação, considerando-se que este era o único meio de ascensão social vislumbrado pela classe de origem.

Na infância, destacaram-se pelo bom desempenho escolar e parcas oportunidades de diversões. Na adolescência, os sentimentos de inferioridade e humildade excessiva - muitas vezes impostos ao negro no convívio social - disfarçados por timidez e a busca da aceitação de pessoas de camadas sociais mais elevadas, foram os primeiros obstáculos a serem superados para atingirem o sucesso.

Introjetaram, precocemente, a idéia de que teriam que ser os melhores para sereia aceitos como “iguais". Isso foi buscado tanto na trajetória escolar como no cotidiano, lançando mão de diversas estratégias, tais como: sobressaírem-se como indivíduos bem comportados; concentrar esforços no estudo de matérias de maior nível de complexidade; fazer do bom desempenho esco- 
lar a "moeda de barganha” para promover a proximidade dos que Ihe convinham; concentrar esforços nos afazeres que desempenham; extrapolando o nível de dedicação convencional - limites ampliados de atuação nas funções que lhes atribuiam, disponibilidade para ajudar nas tarefas a qualquer hora; raramente ou nunca se insubordinavam contra as atribuições ou com seus superiores; evidenciavam características pautadas na dedicação, seriedade, iniciativa e honestidade.

Elaboraram individualmente a experiência de inserção em camadas sociais mais elevadas, construíndo com habilidade curiosas histórias pessoais. Aquisições vantajosas para produção de um “saber viver” específico e bem sucedido. No entanto, se tornaram experiências únicas e não compartilhadas.

Demonstram ausência de consciência política ou da prática de compartilhar experiências, dificuldades específicas - medos, angústias, frustrações, com aqueles que detém semelhante bagagem social ou emocional.

Alienaram-se dos valores culturais negros, eliminando propositadamente de suas vidas o envolvimento com questões e práticas culturais, religiosas ou não, ligadas à sua condição racial.

A busca para ser o melhor - fruto do senso comum de que o negro tem que trabalhar dobrado - também significou a intensificação de esforços na subida da escala social. A luta exaustiva para vencer desafios resultou em uma vida de constante e permanente tensão, tornando-os mais exigentes consigo mesmos e em especial com seus pares étnicos, aumentando o distanciamento entre eles.

Viveram a experiência de ambiguidade de valores sociais, sucumbindo ao apelo do branquearnento. Por serem as excecões no grupo, adotam como estratégia um novo modelo de identidade: o do grupo dominante (branco), no discurso, no trajar-se, no comportamento, nas relações conjugais e, em muitas vezes, com atitudes preconceituosas e de intolerância para com os outros negros;

O preconceito racial foi a principal barreira enfrentada pelos executivos. A discriminação racial resultante foi assumindo formas cada vez mais elaboradas, constituindo desafios que muitos não se encorajaram a enfrentar.

Torna-se bem nítida a forma desigual com que os negros se inserem no processo de ascensão social e exigindo da sociedade brasileira uma necessária reparação. "O mundo inteiro tem políticas compensatórias de conquista social. Levando-se em conta que se uma comunidade é secularmente posta à margem, a nação tem que se ocupar dela. A medida que os negros não são integrados ao Brasil, isso se torna um risco para a unidade nacional.” (SANTOS, 1995).

Enquanto isso, entendemos que conscientes das dificuldades enfrentadas cabe àqueles que tem ultrapassado barreiras impostas à ascensão, criarem mecanismos de continuidade, não para essas mesmas pessoas, mas para que surjam outros candidatos. E na condição de poder que a discriminação pode ser atacada mais eficientemente.

As considerações anteriores não esgotam as possibilidades heurísticas da grande diversidade e do volume de informações coletadas. Estas estão colocadas à disposição de outros pesquisadores, cujo interesse pelo tema vier a ser despertado ou estimulado.

\section{A GRADECIMENTOS}

Os autores agradecem ao Professor Dr. Joaquim Beato, da Universidade Federal do Espírito Santo, pela colaboração no desenvolvimento da pesquisa e elaboração deste artigo.

\begin{abstract}
This article deals withcertam aspects ofthe childhood andadolescence of black executives working in banking institutions m Salvador (state of Bahia) and attempts to urderstand the events that occurred during these penods and their relation to the executives' route of social ascent in order to underst md the reality of these people. Case studies and life stories were the methods used in this study. The results of the study reveal that ali the executives in the study group came from low income families and that theirparents were the main stimulators oftheir social ascent by encouragmg education and qualification. Racial discrimination was shown to be the main obstacle to their ascent and was confronted with specihc and individual responses, guided by 'a desire to be the best in order to be accepted as an equal'. The study demonstrates the uneven way in which blacks become part ofthe process of social ascent, and how the route of ascent purposely eliminates the black cultural values of the small number of individuais who manage to reach high positions in the institutions, preferring the white as an identity model.
\end{abstract}

Key-words: Racism; Children and work; Family. 


\section{REFERÊNCIAS BIBLIOGRÁFICAS}

BENTO, M. A. d. S. Discriminação racial e resistência na voz de habalhadores negros. Rio de Janeiro, 1992. [Dissertação de Mestrado - Psicologia Social da Pontihcia Universidade Católica do Rio de Jameiro]

BRUSCHIN1, M. C. A Mulher e familia: Cotidiano nas camadas médias paulistanas. São Paulo, Fundação Carlos Chagas/Ed. Revista, 1990.

CLASTRES, P. A Sociedade contra o Estado: pesquisa de antropologia Politica. Rio de Janeiro; Ed. Francisco Alves, 1986.

CURY, C. R. J. Educação e contradição: elementos metodológicos para uma teoria critica do fenômeno educativo. São Paulo; Ed. Cortez, 1985.
HAGUETTE, T. M. F. Metodologia qualitativa na sociologia. Petrópolis Rio de Janerro, Ed. Vozes, 1995.

MINAYO, M. C d. S. O desafio do conhecimento. São Paulo,Hucitec, 1992.

MOURA, C. O negro: de bom escravo a mau cidadão. Rio de Janeiro, Ed. Conquista, 1977.

MOURA, C. Os negros e o sistema educacional brasileiro. Jornal Banta-Nagô, Salvador, nov 1995. 1(3): 02-04.

PIERSON, D. Brancas e pretos na Bahia. São Paulo, Ed. Nacional, 1945.

PRADO, D. Oue é família? São Paulo, Brasiliense, 1981.

SANTOS, M, Entrevista. Folha de São Paulo, Caderno Especial, São Paulo, 25 de jun. 1995. p. 8.

SOUZA, N. S. Tornar-se negra, as vicissitudes da identidade do negro brasileiro em ascensão social. Rio de Janeuo, Ed. Graal,1983. 